\title{
Ricoeur's First Aporia of Time: The Problematics of Visibility vs. Invisibility of Time
}

Hafiz Syed Husain

\begin{abstract}
Ricoeur's hermeneutic phenomenological reflections on the experience of time involve a series of hermeneutic confrontations which present themselves as the historical detour into Western reflective discourse. This detour has three foci inasmuch as the detour involves Ricoeur's first aporia of time: (1) movement, (2) visibility vs. invisibility, and (3) finitude vs. infinity. The present investigation explicates the second of these foci. This explication involves the (re-) constructions of the arguments for implicit or missing theses to develop the fully elaborated account of this moment of detour.
\end{abstract}

Keywords: Ricoeur, Husserl, first aporia of time, hermeneutic phenomenology

\section{Introduction: The Philosophical Significance of the First Aporia of Time}

7 he present investigation is the second in the series of explicating the meaning-structure of time inasmuch as it manifests itself in Western reflective discourse. ${ }^{1}$ Time is one of the ultimate challenges for any mode of reflection, scientific or philosophical. Irrespective of the fact that Greek physics was radically different from modern physics, yet the metaphysical presumption about the conception of time is the same as one of what Ricoeur called the cosmological time, which renders time as the measure of movement in number. ${ }^{2}$ In this conception of time, the present moment is

\footnotetext{
${ }^{1}$ For the first in this series, see Hafiz Syed Husain, "St. Augustine's Confessions vs. Aristotle's Physics: Two Rival Conceptions of Time in the History of Western Thought," in Iliria International Review, 9 (2019), 231-253.

2 Paul Ricoeur, Time and Narrative Vol. I, trans. by Kathleen McLaughlin and David Pellauer (Chicago: The University of Chicago Press, 1984), 15; Paul Ricoeur, Time and Narrative

(c) 2021 Hafiz Syed Husain

https://www.kritike.org/journal/issue 28/husain june2021.pdf

ISSN 1908-7330

(c) BY-NC-ND
} 


\section{RICOEUR'S FIRST APORIA}

represented as the zero-dimensional moving point on Euclidean line such that the line itself is conceived as consisting of distinct points without any gap. This renders past as the part of Euclidean line already traversed by the moving point, and the future as what lies distinctly ahead of the present moment. On the other hand, any phenomenological reflection on the experience of time demonstrates that time involves human experience as a flow of present moments such that these present moments are phenomenologically thickened to internally possess its immediate past and its immediate future. However, both cosmological and phenomenological conceptual models of time are problematic. Ricoeur called the corresponding problematics "the first aporia of time." 3 He discussed these problematics both philosophically and historically at three levels which can be seen as his hermeneutic confrontations between: (1) Aristotle vs. Augustine, (2) Kant vs. Husserl, and (3) "ordinary time" vs. Heidegger. In each case, Aristotle, Kant, and ordinary time correspond to the representative philosophizings for the

Vol. III, trans. by Kathleen McLaughlin and David Pellauer (Chicago: The University of Chicago Press, 1988), 12-22.

${ }^{3}$ Husain, "St. Augustine's Confessions vs. Aristotle's Physics," 244ff. The present investigation about the aporetics of time was part of my PhD work. In that work, I argued that there are at least two ways with which Ricoeur's project of Time and Narrative can be read or interpreted. There is one, which I called "the dominant interpretation," which most Ricoeur scholars have pursued, and the other, which I called "the aporetic interpretation." According to the latter, the project of Time and Narrative is the gateway towards a "hermeneutic phenomenology of time." I worked out this "hermeneutic phenomenology of time" in my $\mathrm{PhD}$ work, which I argued to be a system of interconnected aporias; which I called "The Aporetics." The interconnected web of aporias was elaborated as an organization of Western historical thought which hinged upon three most fundamental aporias. They were respectively calledfollowing Ricoeur's own suggestion: (1) the First Aporia or "cosmological vs. phenomenological," (2) the Second Aporia or "the One and the Many," and (3) the Third Aporia or "the ultimate inscrutability." Ricoeur, Time and Narrative Vol. III, $241 \mathrm{ff}$.

Although, it is beyond the scope of the present investigation to go into the detail of the Second and the Third Aporias, however, a brief elaboration is in order. The Second Aporia, or "the One and the Many," corresponds to the problematics of conceptualizing time as being both: (a) One and (b) Many. In the context of One, it is not only time that is referred as One, but it is the very semantics by virtue of which any particular or singular object has the metaphysical potential of being One-or has a Being. It is the Oneness of time which is responsible for making possible not only "a world with a universal history" but it is also responsible for making possible of the "metaphysics of meaning of this history" exemplified by the Hegelian philosophy of history. Ibid., 193-202. On the other hand, Many correspond to the plurality of time-as in the semantics of "times," (e.g., mortal time, historical time, cosmic time, etc. Ibid., 91-94. Or, as in the dissociation of time into past, present and future: exemplified in Foucault's Archaeology of Knowledge. Ibid., 217ff. The Third Aporia or "the ultimate inscrutability" corresponds to an inherent limitation of human thinking about time. It corresponds to a fateful failure about any conceptualizing of time to be philosophically adequate. Its manifestation corresponded to the archaic remnants throughout Western history of ideas. Ibid., $261 \mathrm{ff}$.

(c) 2021 Hafiz Syed Husain

https://www.kritike.org/journal/issue 28/husain june2021.pdf

ISSN 1908-7330

(c) ) BY-NC-ND 
cosmological conception of time, while Augustine, Husserl, and Heidegger correspond to the same in case of the phenomenological. ${ }^{4}$

At the level of Aristotle vs. Augustine, hermeneutical derivation (HD) of the problematics consisted of a general structure. I presented a detailed exposition ${ }^{5}$ of the structure of HD which I outline here as follows. It involves hermeneutically pinning down the fundamental presumptions of both conceptual models inasmuch as this process consists of a sequence of paradoxes from the argumentative expositions of both Aristotle and Augustine with scrupulous linguistic analysis. Let's call the set of presumptions "Ac" corresponding to cosmological model, and "Ap" corresponding to phenomenological model. Then both $A_{c}$ and Ap form structures constitutive of the philosophical understanding of time in the cosmological thinking of Aristotle and phenomenological thinking of Augustine, respectively. Secondly, these structures are partly mutually exclusive, for they involve some presumptions or aspects which contradict each other. But, more importantly, they are also partly mutually dependent for they involve some theses which presume one another. For instance, one of the basic presumptions which are part of Ap is what I call-following Augustine's confessions - the thesis of distentio animi. According to this: extension in time is the distention of soul. ${ }^{6}$ On the other hand, one of the basic presumptions which are part of Ac is: time is the measure of movement in number. ${ }^{7}$ The hermeneutic analysis leading up to these presumptions from Augustine's confession and Aristotle's Physics shows both tendencies simultaneously. They are mutually exclusive, for distention of soul involves aspects of human experiences which are too psychological to possess any relevance for Aristotle's methods in Physics. Similarly, Aristotle's analysis of bodily movement to account time as quantifiable is too physical to have any significance for phenomenological aspects of temporal experiences. But, the HD of these two theses also shows that both of these theses involve mutual hermeneutic dependence as well. For instance, Aristotle himself realizes the role of language in intending time in context of his analysis of before and after, for these linguistic devices implicitly slip in the role that is played by the mind. ${ }^{8}$ The role of language as intentionality becomes more prominent in Aristotle's analysis of movement when he further realizes that no account of physical movement is sufficient without addressing how things are spoken

${ }^{4}$ Ricoeur, Time and Narrative Vol. I, 13ff; Ricoeur, Time and Narrative Vol. III, 58, 60ff, 81ff, $244 f f$.

${ }^{5}$ Husain, "St. Augustine's Confessions."

${ }^{6}$ Ricoeur, Time and Narrative Vol. I, 21.

${ }^{7}$ Aristotle, Physics 219a2-219b2.

${ }^{8}$ Ibid., 223a-21-22.

(C) 2021 Hafiz Syed Husain

https://www.kritike.org/journal/issue 28/husain june2021.pdf

ISSN 1908-7330 


\section{RICOEUR'S FIRST APORIA}

of "to be in time" 9 or "are in time."10 On the other hand, Augustine's phenomenological analysis towards finding some constitutive principle for human temporality is overburdened with metaphorical configurations which implicitly slip cosmological presumptions. Following Ricoeur, I find one such configuration which I call "the logic of the use of the word transire-'passingaway' or 'to pass'"11 - as laden with metaphorical projection of a moving point traversing through space, which is certainly cosmological. This renders, in the final analysis, the statement of the first aporia of time at the level of its first confrontation as

human-time as expounded by phenomenology is neither derivable from physical-time as expounded by cosmological account nor can it derive physical-time, yet both stand in a dialectical opposition to the extent that they also cannot mutually exclude each other. ${ }^{12}$

This statement may appear representable schematically as the mathematical set theoretic intersection of $\mathrm{Ac}$ and Ap but this would be misleading, for the mutual dependent aspect of theses from the two models does not coincide. This is one reason why the statement of the first aporia as derived above is a genuine hermeneutic achievement which provides novel dialectical opposition.

On the other hand, I have previously shown how Ac is a philosophical presumption of natural science and its corresponding positivist research methodology, whereas Ap is the same for social sciences and the disciplines of humanities with corresponding qualitative research methodology.13 In other words, what is at stake in the philosophical problematics of the first aporia of time is not just how philosophy should pursue its metaphysical investigation of time, but the very possibility of "how to make sense of human action philosophically such that it does not itself get caught up in the traditional metaphysical dichotomies of subject vs. object, physis vs. nomos, mind vs. body etc." In what follows, I pursue the explication of Ricoeur's hermeneutic phenomenological investigation into the problematics of time at the second level, i.e., Kant vs. Husserl.

${ }_{9}$ Ibid., 220b32-222a9.

${ }^{10}$ Ibid., 222b16-223a15.

${ }^{11}$ Husain, “St. Augustine's Confessions," 240.

${ }^{12}$ Ibid., 247.

${ }^{13}$ Hafiz Syed Husain, "Philosophical Reflections on Research Methodology for Social Sciences," Beytulhikme: An International Journal of Philosophy, 9 (2019), 585-596.

(c) 2021 Hafiz Syed Husain

https://www.kritike.org/journal/issue 28/husain june2021.pdf

ISSN 1908-7330

(cc) BY-NC-ND 


\section{Visibility vs. Invisibility of Time}

Husserl's On the Phenomenology of Consciousness of Internal Time ${ }^{14}$ aims to work out the phenomenology of time within his later transcendental framework. This phenomenological investigation aims at phenomenologically "seeing"15 time itself appearing within the field of consciousness. This seeing is not an ordinary perception, but an eidetic intuition under the transcendental attitude. Such an intuition is an originary self-giving intuition in which the object is given "in person." This is claimed to be the "ultimate legitimizing source of all rational assertions."16 Ordinary time is impregnated with false consciousness, among which include most notably the metaphysical presuppositions about transcendently existing objects, among which also include the objective-time, i.e., the transcendent autonomous time. ${ }^{17}$ What is to be bracketed is any presupposition about the existence of this objective time in natural attitude so that one can develop that phenomenological gaze with the help of which signs and expressions of time which are purified from all unwanted metaphysical worries would turn to time to show as-it-is-in-itself within the field of transcendental consciousness. ${ }^{18}$ These pure signs and expressions are the hyletic data, the elementary unities corresponding to the consciousness of internal time. They correspond to what Husserl called time-objects or temporal objects (zeitobject). ${ }^{19}$ This "in-itself" is the "internal time" in the title. It is this internal time that Husserl would find to be the key in accounting for the constitution of objective time. ${ }^{20}$ Visibility or intuition of time - phenomenologically speakingwould then correspond to the phenomenological description of this immanent time inasmuch as this description or intuition is principally constitutive of objective or cosmological time.

\footnotetext{
${ }^{14}$ Edmund Husserl, On the Phenomenology of the Consciousness of Internal Time, trans. by J. B. Brough (Dordrechts: Kluwer Academic Publishers, 1991).

15 This seeing is what captures the final phenomenological observation. For textual evidence, cf. Husserl, On the Phenomenology of the Consciousness of Internal Time, 82: "One can say nothing further than 'look'" as he reaches the ultimate constitutive principle "absolute flux," or cf. Ricoeur, Time and Narrative Vol. III, 41.

${ }^{16}$ Edmund Husserl, Ideas Pertaining to a Pure Phenomenology and to a Phenomenological Philosophy: First Book, trans. by Fred Kersten (Hague: Martinus Nijhof, 1983), 36.

${ }^{17}$ Ibid., 25.

18 This is strictly in the line proposed by the so-called Husserlian phenomenology's battle-cry "back to the 'thing themselves'." Edmund Husserl, Logical Investigations Vol. I, trans. by John N. Findlay (New York: Routledge, 2001).

${ }^{19}$ Ibid., $23 \mathrm{ff}$.

${ }^{20}$ See Ricoeur's critique in this paper's section "Limitations for Husserl's Intended Visibility of Time."
}

(C) 2021 Hafiz Syed Husain

https://www.kritike.org/journal/issue 28/husain june2021.pdf

ISSN 1908-7330

(cc) BY-NC-ND 


\section{RICOEUR'S FIRST APORIA}

\section{Husserl's Demonstration for the Visibility of Time}

Husserl's problem of time is apparently twofold. Instead of answering the question "what is time?" which would be too metaphysical and thus has already been bracketed, he must first focus on the specific how of his research, inasmuch as this how is aimed at the self-showing of the phenomenon through phenomenological description. ${ }^{21}$ This will render time as a phenomenological ideality which becomes accessible only after the transcendental reduction is in effect. This ideality is the transcendental structure or shape of experience which is ultimately constitutive of any possible temporal experience. However, for Ricoeur, this would not qualify as the sought "visibility of time" for Husserl must then be able to derive the objective time back. ${ }^{22}$ Latter is - though contestable according to some ${ }^{23}-\mathrm{a}$ necessary step to establish the truth of phenomenological description and thus, it is not external to the description. The idea of truth here is certainly not one of correspondence since the natural attitude is bracketed already. It is the intentional fulfillment of the phenomenological description within the realm of the phenomenological. In what follows, I will explicate Ricoeur's two basic theses about Husserl's proposed phenomenological demonstration for the visibility of time: (1) that Husserl failed in both: establishing the possibility of the pure phenomenological realm and the corresponding intentional fulfillment, and (2) that this failure leads to some of the Kantian presuppositions about the transcendental ideality of time.

\section{The Two Correlated Problems and the Double Intentionality as Its Intended Solution}

First, $\left(\mathrm{A}_{1}\right)$ : "What constitutes this immanent activity and affection intentionally characterized by the threefold intention of primal-retentionprotention?" Second, ( $\left.\mathrm{A}_{2}\right)$ : "How is this achievement or constitution of immanent time brought about such that this immanent time is the one in which immanent acts are constituted inasmuch as this constitutive analysis can describe the constitution of transcendently intended time as well?"24 The latter part is necessary for the intentional fulfillment that will complete the description of the visibility or intuition of time. We will see in what follows, answering the second problem, in correlation with the first, would lead to the problem of intentional fulfillment or the phenomenological truth in terms of which we are required to seek the visibility of time.

\footnotetext{
${ }^{21}$ Chad Engelland, Heidegger's Shadow: Kant, Husserl, and the Transcendental Turn (New York: Routledge, 2017), 54.

${ }_{22}$ Ricoeur, Time and Narrative Vol. III, 38, 40.

${ }^{23}$ A. D. Smith, Husserl and the Cartesian Meditations (New York: Routledge, 2003), 12-14.

24 "Consciousness of time requires time" (Husserl, On the Phenomenology of the Consciousness of Internal Time, 198).

(c) 2021 Hafiz Syed Husain

https://www.kritike.org/journal/issue 28/husain june2021.pdf

ISSN 1908-7330
}

(c) BY-NC-ND 
To answer the first question, there has to be some constitutive principle to avoid an infinite regress. ${ }^{25}$ It is this constitutive principle that Husserl calls absolute consciousness, absolute flux, or flow. ${ }^{26}$ Absolute consciousness is the ultimate bedrock to which Husserl had avoided vesting any immanent content as such. Furthermore, absolute flow constitutes itself. It is this paradoxical phenomenon which Husserl admitted as being both wonder and scandal. ${ }^{27}$ Husserl clearly admits that the flow or flux are merely metaphors for they cannot accurately or non-transparently refer to this phenomenon. But these metaphors are useful, for they help capture the possibility of naming that is in declarative sense un-namable. ${ }^{28}$ It has - in fact, it is - the continuum of phases consisting of immanent activity as affection or modification, itself temporally constituted by impressional consciousness or the threefold intentional structure as a particular phase. Flow is the metaphor corresponding to this continuum of phases without actually possessing anything as content that actually flows. Time, as immanent time and not the transcendent time of cosmological type, thus becomes the achievement of this absolute time-constituting consciousness.

To respond to the second question, Husserl proposes his theory of double intentionality, the longitudinal intentionality (Längsintentionalität) and transverse intentionality (Querintentionalität)..$^{29}$ They correspond to the two aspects of retentional consciousness as if they are the two directions of flow inasmuch as former renders the self-appearance of the absolute flowas pre-reflective self-consciousness ${ }^{30}$ - whereas the latter constitutes the immanent acts (the act of perception, recollection, imagination, etc.) atemporally. Both longitudinal and transversal are non-object intentionalities. ${ }^{31}$ Immanent acts are not temporally extended. Although, once thematized, they do appear to be temporally extended reflectively. ${ }^{32}$ From longitudinal intentional side, absolute consciousness or flow not only brings about itself as self-appearing but simultaneously it brings about the unity of

25 Ibid., 84, 199. For infinite regress and Grundsatz, cf. Hafiz Syed Husain, "Schleiermacher's Universal Hermeneutics and the Problematics of Rule-Following," in Science E Philosophy, 6 (2018), 3-14.

26 One of Husserl's exact phrase for it is "absolute time-constituting flow of consciousness." Husserl, On the Phenomenology of the Consciousness of Internal Time, 77.

27 Ibid., 390.

${ }^{28}$ Ibid., 382.

${ }^{29}$ For horizontal, cf. ibid., 85, 391; for transverse or longitudinal intentionality, cf. ibid., 86, 392.

${ }^{30}$ Dan Zahavi, "Inner Time-Consciousness and Pre-reflective Self-awareness," in The New Husserl: A Critical Reader, ed. by Donn Welton (Bloomington: Indiana University Press, 2003), 157-180.

${ }^{31}$ This is important to emphasize if one wants to avoid falsely alleging Husserl of the "Reflectionist Model" of self-consciousness. For detail, cf. ibid.

${ }^{32}$ Ibid., $168-169$.

(C) 2021 Hafiz Syed Husain

https://www.kritike.org/journal/issue 28/husain june2021.pdf

ISSN 1908-7330

(cc) BY-NC-ND 
the immanent act as well. This is why there is always a "mine-ness" in each and every experience (Erlebnis) making this experience the experience of a particular consciousness. ${ }^{33}$ With transverse intentionality, each now-phase of the absolute flow already retains and thus intends the previous flows as the passing-away of now-phases, producing the possibility of "fusion of phases." 34 Each phase has a horizon of its depth, its limit of retaining the maximum preceded primal impression, implying that it is possible to talk about fusion of horizons. This gives rise to the multiple possibilities of interpretations.

\section{Two-Level vs Three-Level Interpretations}

Since phenomenological description aims at thematizing what is prereflective, and since Husserl's idealist turn after Ideas I explicitly denied that the immanent acts are perspectival, 35 we are left with two options for interpreting the number of levels with which this phenomenology yields for time-constitution. There is one which Ricoeur has taken, which I call the "three-level" interpretation, and there is one which I call the "two-level" interpretation which has been advocated by Zahavi. In Ricoeur's "threelevel" interpretation, time-consciousness or time-constitution involves three correlated but descriptively distinct levels. There is one (1) where transcendent object is temporally constituted (the one we bracketed), (2) the immanent level (or subjective level) where immanent acts are constituted as processes and intended via non-objectifying transverse intentionality, and finally (3) the atemporal level of absolute flow where the formal unity of impressional consciousness is constituted. The latter is intended by longitudinal intentionality. ${ }^{36}$ Ricoeur's reading of Husserl entails that the phenomenological description as a detour reached its zenith at the purest level with level three where pre-reflective self-consciousness is also thematized. Now it must return and lift the bracket and explain the constitution of objective time. Secondly, Ricoeur assumes that this return to objective time must not presume objective time for it would render the whole phenomenological demonstration of detour-return viciously circular. This problem still remains, for the second problem $\left(\mathrm{A}_{2}\right)$ stated at the beginning of this section has not been adequately answered as yet.

33 "There is one, unique flow of consciousness in which both the unity of the tone in immanent time and the unity of the flow of consciousness itself become constituted at once." Husserl, On the Phenomenology of the Consciousness of Internal Time, 84.

${ }^{34}$ Ricoeur apparently does not present us the same picture and vocabulary, but Ricoeur's use of the term "modification" in context of impressional consciousness and the "fusion" of source-points leads to the same conclusion.

${ }^{35}$ Husserl, Ideas Pertaining to a Pure Phenomenology, 101-106, 113.

${ }^{36}$ Ricoeur, Time and Narrative Vol. III, 40.

(c) 2021 Hafiz Syed Husain

https://www.kritike.org/journal/issue 28/husain june2021.pdf

ISSN 1908-7330

(c) $\mathrm{BY}-\mathrm{NC}-\mathrm{ND}$ 
Limitations of Husserl's Intended Visibility of Time

From the two correlated problems which absolute flow and the double intentionality intended to solve, we arrived in the preceding section on a further problem which may be stated as: $\left(\mathrm{A}_{3}\right)$ : "How must the constitution of objective time from the description so obtained be described without presuming it?' If we can do that, then doing that is the sought intentional fulfillment which would establish the originary intuition-or visibility - of time..$^{37}$

In attempting to derive the objective time back, ${ }^{38}$ Husserl explicitly admitted the surge of metaphorical possibilities within the language of phenomenological descriptions, especially in context of calling absolute consciousness a flow which was actually not a flow since it had no content as such. He helplessly metaphorized it as the unnamable. ${ }^{39}$ Ricoeur identifies a whole lot of such metaphorical outpouring in Husserl's constitutive analysis. Some of them include: "to be" and its tensed variations, "still," "place," "flux/flow," "source-point," "sinking back," "springing up," etc. They are found in phenomenological description of the constitution of objective time from the immanent time. ${ }^{40}$ They allude to a possibility of figuration of phenomenological time or the immanent time. But this figuration of livedtime should not be allowed since what phenomenology aimed after was an originary intuition of lived or immanent time as the phenomenological capturing of the unthematic immanent affection: the absolute flow-the continuum of phases of impressional consciousness. To this originary intuition, no symbolization was required. In fact, metaphorical symbolizing or figuration actually compromises the originariness in the phenomenologically thematic reflection, for they are primary examples of empty intentions, right opposite of the self-giving originary intention. But the inevitability of metaphorical mediation in the corresponding linguistic articulation as phenomenological description of lived-time provides ample evidence that there is no firsthand originary intuition of lived-time available in the very first place to a phenomenological "gaze." What is more important is that these metaphorizings within phenomenological description attest to presuming objective time, something which we already claimed would render the whole demonstration circular.

${ }^{37}$ Note that, though originary intuition is usually associated with self-giving acts with model as act of perception, which is radically different from the presentifying acts such as reflection or recollection. However, as we have already cited above, Ricoeur's reading of Husserl also entails a possibility of originary intuition in reflection, though he explicitly mentions that the mode of originary self-givennes are different in the two kinds of acts. See Ricoeur, Time and Narrative Vol. III, 41.

${ }^{38}$ Husserl, On the Phenomenology of the Consciousness of Internal Time, 64-76.

${ }^{39} \mathrm{Ibid} ., 382$.

${ }^{40}$ Ibid.; Ricoeur, Time and Narrative Vol. III, 41.

(C) 2021 Hafiz Syed Husain

https://www.kritike.org/journal/issue 28/husain june2021.pdf

ISSN 1908-7330

(cc) BY-NC-ND 
For instance, Husserl considers formal structure of objective time series, which renders it simultaneously both one and many. According to this formal structure, objective time is one in the sense that we refer time as a whole within-which time(s) occur. It is what renders time as both universal and whole. One natural or empirical manifestation of this oneness is its arithmetization in the uses of calendar in historical sciences. ${ }^{41}$ However, time is also many, in the sense, that to each and every now-point in objective time, there is always a distinct past, and a distinct future. ${ }^{42}$ The formal aspect of objective time is what is constitutive of these possibilities irrespective of any historical or material or immanent content. In order to make sense of the above formal aspect of objective time, Husserl makes use of the notion of "temporal position" which, according to Ricoeur, is a key concept for the desired phenomenological return to objective time. Since, bracketing had shifted the focus from natural to phenomenological attitude, what the detour moment of phenomenological demonstration involved was only the immanent or the material content. In attempting to get back the formal structure of objective time back from the demonstration presented the problem of accounting how to identify the formal content-i.e., temporal position - and the material content. This is important for such identification is tacitly being presumed in everyday life. In order to account for this identification, Husserl resorts to further metaphorical figurations such that the metaphorical status of the "temporal position" itself remains unbridgeable from the detour moment of demonstration.

All Husserl offers, according to Ricoeur, is nothing but an analogy between the constitution of immanent and transcendent unities. Thus, just as adumbrations of sensations, i.e., the primal data of the presentation of sensations in lived-time, follow the law of primal succession via rententional intention as immanent modifications or affections, so we find similar adumbrations in physical things corresponding to which the appearances form the data of primal impression. ${ }^{33}$ According to Ricoeur, this account is circular. $^{44}$ It is symptomatic of the implicit enigma in any pure phenomenological attempt to solve for the constitution of time in terms of lived-time. For what had to be demonstrated as the backward return moment of Husserl's demonstration as derivation of objective time was simply posited on the basis of analogy with what should have been used as a phenomenological premise. The metaphorical aspect of phenomenological

${ }^{41}$ Ricoeur, Time and Narrative Vol. III, $105 \mathrm{ff}$.

${ }^{42}$ So, for instance, the now-point that corresponded to Newton had a distinct past from the now-point of our today, since, we have seen later developments in the form of Einstein and Bohr, which Newton could not have imagined.

${ }^{43}$ Husserl, On the Phenomenology of the Consciousness of Internal Time, 73-75.

${ }^{44}$ Ricoeur, Time and Narrative Vol. III, 44.

(c) 2021 Hafiz Syed Husain

https://www.kritike.org/journal/issue 28/husain june2021.pdf

ISSN 1908-7330

(cc) BY-NC-ND 
vocabulary coupled with analogizing the derivation of objective time shows that phenomenology is not only being unable to sufficiently subsume cosmological autonomy of time as objective time under phenomenological account of human or lived-time, but also, as a result of referential opacity of phenomenological descriptive discourse struck by helpless implicit recourse to metaphorizing, phenomenology cannot help but find refuge in presuming its apparent antithesis, the ultimate invisibility of time.

\section{Kant's Transcendental Ideality of Time and its Implicit Phenomenological Presumptions}

By transcendental ideality of time, we mean time as being the ultimate condition for the possibility of any intuition of which itself no intuition is possible. This may sound contrary to Kant's calling time as intuition a priori. In metaphysical exposition of space and time we find him explicitly saying, "Inner sense, by means of which the mind [das Gemüt] intuits itself, or its inner state, gives, to be sure, no intuition of the soul itself, as an object." 45 To this inner-sense, Kant attributed time as its form. Again, we find him saying, "Time is nothing other than the form of inner sense, i.e., of the intuition of our self and our inner state." 46 It is this status of time, i.e., the form of inner-sense, which determines transcendental ideality of time different from space.

\section{A Brief Synopsis ${ }^{47}$}

According to Ricoeur, Kant's transcendental method suppresses phenomenological underpinnings. This has been the case especially on four occasions in the Critique of Pure Reason, in the discourse of (1) "Aesthetic" and the (2) "Analytics," (3) the text of "self-affection" (Selbstaffektion) that Kant added as an appendix to his theory of figurative synthesis in section 24 of second transcendental deduction (also known as "deduction-B"), and finally (4) the text that Kant added in second edition under the title "Refutation of Idealism". ${ }^{48}$ Ricoeur finds them pairwise logically connected ((1)-(2) and (3)(4)) with mutual occlusive aspects of both phenomenology and Kant's transcendental philosophy gradually increasing. In the pair of (1)-(2), Kant

\footnotetext{
${ }^{45}$ Immanuel Kant, Critique of Pure Reason, ed. and trans. by Paul Guyer and Allen W. Wood (New York: Cambridge University Press, 1998), 174 (A22/B37).

${ }^{46}$ Ibid., 163 (A33/B49).

47 This summarizes the basic strategy of Ricoeur. See Ricoeur, Time and Narrative Vol. III, 44-59. Many of the theses are not explicitly stated by Ricoeur. A tentative reconstruction of the complete demonstration is presented in the following sections.

${ }^{48}$ Kant, Critique of Pure Reason, 326-329 (B274-270).
}

(C) 2021 Hafiz Syed Husain https://www.kritike.org/journal/issue 28/husain june2021.pdf ISSN 1908-7330 
apparently excludes phenomenology but implicitly presumes it. ${ }^{49}$ However, as we reach the second pair, there are corresponding presumptions which can be reconstructed, but it is the exclusion of phenomenology that is really at issue. Although the second pair is already part of the "Analytic," I think it requires a separate mentioning for this reason of occlusion which would bring forth the aporetic character of this confrontation.

\section{The First Pair: The Discourse of Aesthetic vs. Analytic}

In the first two arguments, Kant's regressive aspect acknowledges time to be spoken of only in fragmented fashion. ${ }^{50}$ The route of regression from either objects with temporal predicates or with thought-experiment, shows that time is always found to be already applied as modifications of succession, simultaneity, or as linguistic articulations of "in time." Since it is not a generic concept (by third argument), its application is not one of rule that we can work out to make sense of how this is always "already-applied." There is no recourse beyond these primary modifications and the analytic of linguistic articulations, yet it is presumed to be one and unique (third and fourth arguments). ${ }^{51}$ How do we come about that it is, and beyond such fragments? In other words, time is not a concept, not an intuition as such, and also not an application of any particular concept or universal on any particular intuition: yet it exists and we are able to intend it. The enigma implicit in this is the following: How do we come about that time has an existence-in this case transcendentally ideal-given the fact that it is none of the following: concept, intuition, application of any prior concept upon any intuition. If no recourse to lived-experience is allowed, this enigma, at least at the level of "Aesthetic," is unresolvable. Ricoeur proposes a phenomenological remedy to this enigma. The way-out of this enigma is already suggested within the very repression that transcendental argument employs against phenomenology. It is the possibility of having a "vaguevision," which Ricoeur calls temporal horizon that a transcendentalist must already possess of the transcendentally ideal, the "already-applied-ness" of which he is discovering in his "Transcendental Aesthetic." For no other alternative will make it viable to proceed transcendentally. Ricoeur does not explicitly outline the precise phenomenological meaning or demonstration of this temporal horizon, but from his reading of Husserl, this moment of Ricoeur's argument can be reconstructed as follows:

\footnotetext{
${ }^{49}$ Detailed explanations of these aspects are given in the following sections: "The Text of Self-Affection" and "The Refutation of Idealism."

50 The term "Regressive" here is used in the technical sense. It characterizes the method of Kant's transcendental argument. For the detail, see Karl Ameriks, "Kant's Transcendental Deduction as a Regressive Argument," in Kant-Studien, 69 (1978), 273-287.

${ }^{51}$ Kant, Critique of Pure Reason, 162-165 (A30-36), 178-183 (B46-53).

(c) 2021 Hafiz Syed Husain

https://www.kritike.org/journal/issue 28/husain june2021.pdf

ISSN 1908-7330
}

(c) BY-NC-ND 


\begin{abstract}
The fragments involve appearances of objects temporally, so they correspond to the "running-off" modes of appearances of temporal objects. These parallel the immanent content, once we proceed not according to transcendental method but by phenomenological method. This would then ultimately turn the transcendental ideality of time having a possibility of an originary intuition as the "vague-vision" or "temporal horizon" in the corresponding immanent affection which is never thematic but is discoverable only phenomenologically which figures as Absolute Flow through constitution of threefold intentional structure of impressional consciousness. The horizon is not a concept-so Kant is right-but it corresponds to an intuition, which means Kant is wrong as well.
\end{abstract}

However, the enigma is not solved as such but only becomes deeper. Since we now have a possibility of intuition of time, i.e., the "vague-vision" or temporal horizon, which Kant's transcendental ideality explicitly prohibits. Kant's transcendental idealism cannot accept Husserl's thesis of visibility of time. But it needs its phenomenological repository to found the account of Transcendental Aesthetic, only to end up accepting the possibility that this help must slip in as an indispensible consequence-the visibility.

The same fate is met in the discourse of the "Analytic." When time is conceived as a pure form of inner-sense, any possibility of experience mutually grounds both, the ultimate preconditions of the possibility of experience and how these preconditions are to be seen in association with time. Categories as "concepts of an object in general" were already found to be such preconditions. ${ }^{52}$ But understanding required the act of productive imagination to produce synthetic unities which contain the manifolds on which categories are applied. They cannot be applied directly since there is no homogeneity of any kind between the manifold of intuition in which or through which objects are given, and the categories, for latter are the pure concepts a priori. A mediation is thus required that provides a rule by virtue of which these pure concepts a priori become applicable. This mediation is provided by transcendental schemata. ${ }^{53} \mathrm{~A}$ schema can be considered as a solution to "how does a universal become applicable to a particular?" or the condition which determines the intuition under a corresponding concept.

52 Ibid., 224 (A95/B1280).

${ }^{53}$ Ibid., 271ff (A137-139/B176-178).

(C) 2021 Hafiz Syed Husain https://www.kritike.org/journal/issue 28/husain june2021.pdf ISSN 1908-7330 


\section{RICOEUR'S FIRST APORIA}

Every concept, whether empirical, which are homogeneous with their manifold of intuition, or pure concepts which are less homogenous, or transcendental (e.g., categories) which are not so, requires this mediation. For instance, number is an example of a schema (neither transcendental nor empirical) of magnitude, i.e., transcendental determination of time as timeseries to which mathematical conceptualizing of number is a concept. Kant's exact phrasing is different though. He regards magnitude as the transcendental schema of which number is a conceptual determination. ${ }^{54}$ Seen in this context, categories are never temporal horizons, and thus, we are left with an unexplainable mystery-burying phenomenological possibility of "vague-intuition" into the depth of human soul. ${ }^{55}$ The thesis: "Thoughts without content are empty, intuitions without concept are blind" 56 denies any phenomenological originary intuition. Since we have already seen how any description of absolute flow involves metaphorizing, thus, according to Kant, phenomenology is playing with blind intuitions.

It is the third set of principles, "Analogies of Experience," that Ricoeur finds comparatively more exemplary of how the discourse of "Analytic" suppresses phenomenology. This suppression primarily involves answering: how time's transcendental determination (as order relation) reciprocally involves the possibility of experience in general inasmuch as this question is answered by transcendental reasoning only, i.e., without any recourse to lived-experience? This transcendental reasoning starts from a representation of time that is itself determined in the form of a general principle: "As regards their existence, all appearances stand a priori under rules of the determination of their relation to each other in one time." ${ }^{57}$ If this is read in the light of its restatement from second edition, we obtain two most important constituents of this principle; (1) representations of necessary connections within appearances (perceptions), (2) their relation in "one" time. The account of "Analogies of Experience" is a discursive employment of the schemata of substance, cause and community which are here names of the transcendental determinations of time as order relation from which we derive the possibility of all that persists through change as the "Principle of Persistence (Substance)" (First Analogy), the possibility of all that that can be causally connected through temporal successions as the "Principle of Temporal Sequence according to the Law of Causality" (Second Analogy), and finally, the possibility of all that can be interactive as the "Principle of Simultaneity according to the Law of Interaction or Community" (Third Analogy). In each case, there is no possibility of time appearing as form of

${ }^{54}$ Kant, Critique of Pure Reason, 274 (A142/B182).

${ }^{55}$ Ibid., 272 (A140/B179).

${ }^{56}$ Ibid., 193-194 (A51/B75).

${ }^{57}$ Ricoeur cites it from first edition as A127, which is a typo as it should be A176. 
inner-sense per se. The discourse of three Analogies of Experience consists of proofs or philosophical clarifications of these principles very much like theorems. Although the account of analogies involve intuitions of objects in change, in succession (e.g., a ship sailing down the river-stream and successive appearances of a house in "Second Analogy") 58 and in interaction, but this involvement of intuition only serves the purpose of what is involved in the conceptual clarification of the corresponding phenomena and is not aimed at determining signs and expressions to intend time through lived-experience. For instance, in First Analogy, persistence of time is neither spoken through retention of Husserlian type nor by describing through the lived-experience of what is captured by the logic of the use of the word adhuc (still/yet to come) in "present" as we may have found in Augustine, but argued regressively by starting from relation between what persists and changes during59 the existence of a phenomenon or an appearance towards that which must be presupposed for there to be such a possibility. This regressive analytic then involves the mediation of the account of transcendental schema of substance as "the permanence of real in time" ${ }^{60}$ (which was already worked out in the doctrine of schematism as what renders the possibility of all judgments about permanence or objectivity) which finally results in the Principle of Substance (First Analogy). ${ }^{61}$ Principle of Substance is in fact the maximum we can come to understand oneness/unity/persistence/immutability of time as a form of inner-sense. It is Principle of Substance the meaning of which is established by the proof/clarification, that represents "what it means to persist for time itself" via "what it means for a phenomenon to persists in time," where "in time" marks the key distinction between oneness of object that persists and the "oneness" of time that lets this persistence possible. In the absence of phenomenology, "in time" is nothing but the mediation of substance as transcendental schema, which brings us back to the Principle of Substance. In short, we have oneness of time established not by some description of lived-experience but by argument, which establishes this oneness in terms of oneness of object in existence. The gap remains between oneness of time and the oneness of object (Principle of Substance), for the gap was to be filled by what mediated the understanding of this oneness, the schema of substance. But Kant does not go behind the schematism. Instead, in order to make sense of the schematism, Kant takes the detour through the Grundsätze without ever going back, for

${ }^{58}$ Kant, Critique of Pure Reason, 307 (A192/B237).

${ }^{59}$ Kant regarded duration, succession, and co-existence as three modes of time. Ibid., 296 (A177/B219).

${ }^{60} \mathrm{Ibid} ., 275$ (A144/B183).

${ }^{61}$ The statement reads as: All appearances contain that which persists (substance) as the object itself, and that which can change as its mere determination, i.e., a way in which the object exists. Ibid., 299 (A182/B224).

(C) 2021 Hafiz Syed Husain

https://www.kritike.org/journal/issue 28/husain june2021.pdf

ISSN 1908-7330 
what was behind the schematism was already set aside as a hidden mystery laid within the depths of our souls. ${ }^{62}$ This way, transcendental reasoning escapes becoming circular. But the gap remains between the oneness of time and the oneness of objective world. This gap can only be filled again by having a possibility of an intention with which these onenesses can be determined as connected. Argument alone cannot fill in this gap. But this requires the possibility of time appearing within lived-experience as signs and expressions (modes of running-off) which would ultimately lead towards Husserl's double-intentionality (longitudinal-transverse). But this is prohibited explicitly by claiming "time cannot be perceived in itself." 63 This shows that Kant implicitly presupposes Husserlian phenomenological constitution of time but either represses it or conceals it behind the transcendental argument.

One similarly finds a concealment of phenomenology in both Second and Third Analogy. Kant's account on succession as a mode of time which is argumentatively captured in the form of Principle of Causality (Second Analogy; "time cannot be perceived in itself" can similarly be viewed as starting with ways succession as a concept is employed. Conceptual clarification produces a distinction of objective and subjective senses in this employment. ${ }^{64}$ It is this distinction that directs (regressively and not intentionally) towards a rule that has to be applied that makes such distinctions possible. It is this rule the schema of which was causality, ${ }^{65}$ which posits the objectivity of events as happening to us without a sheer possibility of subjective freedom. Husserl had facilitated this in the distinction between primary and secondary remembrance, for it was in secondary remembrance that the door of imaginative construction could open up the possibility of selfreflection. Kant's corresponding Grundsatz in Second Analogy is what turns the undifferentiated chaos of particulars into understanding in terms of judgments. However, as we have seen with Husserl, phenomenology was unable to derive the objective time from immanent time, the objective succession interpreted in terms of "event as actually happening" could not be explained as an external or objective relation within phenomenology.

So, we have insights from Kant's transcendental philosophy that complement phenomenological insights without refuting it. Phenomenology did not reject this objective or ordered succession (and its distinction from subjective aspects) but was unable to account for it. Kant's transcendental idealism substantiates it as an external or objective relation but is unable to

${ }^{62}$ Ibid., 272 (A140/B179).

${ }^{63}$ Ibid., 304 (B233).

${ }^{64}$ Cf. Kant's own examples of "ship sailing" and "appearance of house." Ibid., 306ff (A192ff/B237ff).

${ }^{65}$ Ibid., 304 (A144/B184).

(c) 2021 Hafiz Syed Husain

https://www.kritike.org/journal/issue 28/husain june2021.pdf

ISSN 1908-7330

(cc) BY-NC-ND 
account for the origin of this order, for the origin of this order is time per se which escapes all attempts to be founded as one. According to Ricoeur, any theory of time based on such a distinction must ground its account or justification on something external to this distinction. He thinks that Kant tried to do that in terms of yet another distinction, the distinction of object of this ordered successive apprehensions and the representations of these apprehensions as such. But this cannot account for the present and its irreducibility to an instant. In fact, to account for the "events as what happens" what one needs is more than ordered successions. Although, this may be a better exposition than Aristotle's mere instants which were mutually indistinguishable, for these objective or ordered successions are not indistinguishable as such because they are always "apperceptions," i.e., the result of "I think" accompanying all such representation. ${ }^{66}$ Since Kant is not able to dig underneath this "I" of "I think," for what lies in the "I" of "I think" is unknowable besides being a transcendental principle of unity of apperception, we are still ultimately left with indistinguishable instants depending upon the spontaneous act of soul.

The Second Pair: The Text of Self-affection (Selbstaffektion) vs. Refutation of Idealism ${ }^{67}$

This pair is dominated by the repression of phenomenology and renders its occlusion from transcendental perspective.

\section{The Text of Self-affection (Selbstaffektion)}

The occlusion of phenomenology results when the reading of the text on self-affection is guided by a paradox identified within the very phenomenon of understanding which reinforces the invisibility of time, along with a proposed Kantian response to the paradox. Repression or occlusion here simply amounts to the silence on any possibility of recourse to what is immanent while accounting for subjective self-consciousness. Ricoeur neither did explicitly derive the paradox nor did he discuss Kantian response to the paradox as such. My presentation here is both a probable reconstruction of this derivation and the corresponding Kantian response from Ricoeur's text. The reasoning leading to the paradox can be reconstructed as follows. All of its major claims are already explicated in the preceding sections.

Reconstruction of the Argument Leading to the Paradox and the Probable Kantian Response

${ }^{66}$ Ibid., 246ff (B132ff). This is also known as "Deduction-B."

${ }^{67}$ Both of these are additions Kant made in the second edition of his first Critique. From this point onwards, presentation of (3) self-affection (Selbstaffektion) will be cited from B152-157 and (4) Refutation of Idealism from B274-279.

(C) 2021 Hafiz Syed Husain

https://www.kritike.org/journal/issue 28/husain june2021.pdf

ISSN 1908-7330 


\section{RICOEUR'S FIRST APORIA}

The "Aesthetic" already established that every possibility of experience presumes both space and time as a priori forms of external and inner senses, respectively. Thus, every representation of an object consists of two aspects, one spatial and the other temporal. We have already seen (again primarily from "Aesthetic") that inner-sense is impossible to appear as a representation. But the discourse of "Analytic" established that this innersense is definitely affective or spontaneously productive via schematism as instructions for the faculty of productive imagination to synthesize a manifold of intuition coming from sensibility under concepts coming from understanding. But how these instructions (schemata) represent this innersense, which is the source of affection, remained an unanswered problem, once Kant declared the causal procedure of the transcendental schemata to be hidden in the depth of our souls. Thus, we have the dimension of spontaneous productive activity or affection, which is unable to produce itself as determined representation. Now what if the object of our representation is our own self as the source of this affection? We do represent ourselves empirically. But we already know from Transcendental Deduction that it is impossible to represent our own self as the transcendental self (the self-in-itself) which is after all the ultimate source of this affection. Thus, this implies that we cannot represent or intuit our own acts in themselves (as long as they have their origin in the transcendental self), but we can represent or intuit them inasmuch as they can affect us internally. It is only in the latter sense that we appear to ourselves empirically. But the "Aesthetic" had already established that every representation requires both time and space and that "Analytic" requires that every representation is determined. "Determined" here means that it involves schematically producing spatial synthetic figures. ${ }^{68}$ It is at this point the paradox is driven home: "How could this self simultaneously be both affective and be determined or passive?" Kant's answer to the paradox is: affecting is still determining. ${ }^{69}$ For we may have no direct access to time, or equivalently, this affection, we can represent it as determined in spatial synthetic configurations which are products of synthetic imagination. Beyond this determination, affection is a noumenon. So time still considered to be impossible to intuit, yet finds possibilities of determination in both mathematics and the works of art. ${ }^{70}$ Kant's own examples are quite representative of how mathematics is an instance of such a representation. Samantha Matherne has discussed how

${ }^{68} \mathrm{Kant}^{\prime} \mathrm{s}$ own examples consist of tracing curves through a moving point as an act of production of synthetic figuration (B154-155).

${ }^{69}$ Kant, Critique of Pure Reason, 258-259 (B155-156).

${ }^{70}$ Cf. Samantha Matherne, "Kant and the Art of Schematism," Kantian Review, 19 (2014), 181-205. The same theme is also discussed in Husain, "Schleiermacher's Universal Hermeneutics." Also, this is among the points where Ricoeur finds Kant's insight very relevant for how we have the possibility of responding to the First Aporia of Time in the form of narrative identity. See Ricoeur, Time and Narrative Vol. I, 68ff.

(c) 2021 Hafiz Syed Husain

https://www.kritike.org/journal/issue 28/husain june2021.pdf

ISSN 1908-7330

(c) $\mathrm{BY}-\mathrm{NC}-\mathrm{ND}$ 
this can be extended to any artistic or skillful activity. ${ }^{71}$ Hence, we find a parallelism between effectivity of external world and affectivity of innersense both of which find the possibility of representation or determination through spatial synthetic configurations. Former was discussed in the discourse on "Aesthetic" latter is discussed within "Analytic" (the text of selfaffection (Selbstaffektion)). In latter case, the act of such a spatial synthetic configuration is where we find both the apparent resolution of the paradox and the quasi-equivalence of act and the agent or self. So for instance, following Paul Guyer ${ }^{72}$ and Matherne, we may include the works of art as exemplifications of spatial synthetic configurations. For Kant, every work of art (Kunst) is a cooperation of the faculty of imagination and understanding inasmuch as understanding provides the determining concept and imagination serves like the instrument which helps achieve the presentation of that concept such that the nature of the cooperation is not dictated by any particular logic, but rather by the free-play of imagination (through creative synthesis of aesthetic ideas) of the naturally gifted genius (the artist). In this sense, works of art provide the model example for objects which are not only representations of a particular original talent of human-self (the artist), but by affecting the same human-self, 73 they are also the primary mode of selfaffection (Selbstaffektion). The latter is the case: first, because self-affection means affection which has inner-sense itself as its source; ${ }^{74}$ second, as Matherne has shown that, according to Kant, the artistic creativity parallels the act of schematism with origin in the spontaneous act of transcendental self, so the origin of the work of art has its origin in the artistic-self. This demystifies the phenomenon of self-affection in terms the affectivity of the works of art. To understand how self-affection is also self-determining (i.e., exemplifying Kantian solution of the paradox), and given the fact that Ricoeur's conception of narrative emplotment draws heavily from Kantian doctrine of schematism (though with some reservations ${ }^{75}$ ), we may take Ricoeur's conception of narrative identity to understand what is involved in Kantian solution of the paradox. Ricoeur has shown that narrative identity-which necessarily emerges from the narrative works of art-is what constitutes the possibility of self-representation. This narrative identity ${ }^{76}$ emerges as a result of threefold

\footnotetext{
${ }^{71}$ Matherne, "Kant and the Art of Schematism."

72 Paul Guyer, Kant and the Claims of Knowledge (New York: Cambridge University Press, 1987), 174; Paul Guyer, Kant (New York: Routledge, 2006), 98-99.

${ }^{73}$ This affectivity is twofold: affectivity corresponding to the creative act of the artist and the affectivity corresponding to the product as the end-achievement. This end-achievement is the determinate concept produced by the faculty of understanding for which the faculty of imagination is like the instrument. See Matherne, "Kant and the Art of Schematism."

${ }^{74}$ Kant, Critique of Pure Reason, 327 (B275).

${ }^{75}$ Ricoeur, Time and Narrative Vol. I, 68.

${ }^{76}$ Ricoeur, Time and Narrative Vol. III, 246.
} 


\section{RICOEUR'S FIRST APORIA}

mimesis ${ }^{77}$ which both the reader and the writer of the narrative work schematize in order to achieve self-representation. For instance, Ricoeur attributes the narrative's configuration (mimesis-2) to the joint work of the author and reader. Here he draws on the kinship between narrative's configuration and Kant's concept of the productive imagination as schemating a synthetic operation. However, this self-representation is unstable (not absolute), for there are always competing interpretations of the narrative works. Since we have already seen above how works of art provide a possibility for self-affection, with the help of narrative identity, this selfaffection becomes self-representation (although unstable). Note that paradox is resolved apparently until one does not realize that the whole argument of transcendental philosophy hinges upon phenomenological presupposition. I have made this elaboration to show that Kantian argument makes sense until we follow through Ricoeur's critical confrontation of Kant and Husserl. Thus, what we ultimately have, as access to self-consciousness, is the external determination of subjectivity through works of art. Since, this would always involve natural attitude, phenomenology is not concealed but occluded. This occlusion is further attested in similar manner in the following section.

\section{The Refutation of Idealism}

The fourth and final occasion where Ricoeur presents or traces the confrontation between Kant's transcendental idealism and Husserl's phenomenology is the appended text of "Refutation of Idealism." Its primary function is to subordinate the self-affection (Selbstaffektion), i.e., affection which has inner-sense itself as its source, to affection from outer or external world. ${ }^{78}$ Once this is achieved, the problem of external world would dissolve, for it surfaces only when our philosophical reflections distinguish consciousness of things from the kind of consciousness we have of ourselves such that only the latter is claimed to have the character of certainty. How does Kant propose to achieve this subordination? Also, what precisely do we mean by "consciousness of existence" (which is involved in the problem)? Ricoeur clearly remarked this term with suspicion. It is difficult to make sense of what Kant really means by the phrase "consciousness of existence,"79 especially given the fact that existence is not a concept or predicate. ${ }^{80}$ This is one reason why, very much like "Deduction," "Refutation of Idealism" is still a matter of contention among Kantian Scholars and interpreters. I must state that even Ricoeur seems to be not very clear at this point of how the achievement of the primary

\footnotetext{
77 Ricoeur, Time and Narrative Vol. I, 52-75.

${ }^{78}$ Kant, Critique of Pure Reason, 327 (B275).

79 Ibid.

${ }^{80} \mathrm{Ibid} ., 567$ (A599/B627).
}

(c) 2021 Hafiz Syed Husain

https://www.kritike.org/journal/issue 28/husain june2021.pdf

ISSN 1908-7330

(c) BY-NC-ND 
function of "Refutation" can be made sense from Kant. However, if we try to reconstruct what Ricoeur claims, we may have the following.

\section{Reconstruction of the Argument}

"Aesthetic" had just juxtaposed both space and time in arguing for "how is manifold of intuition possible?" "Analytic" did connect them, but at the level of representation only. The question of "consciousness of existence" whether of things or our own self as the empirical self, is much deeper than what can be accounted in terms of representations alone. What is required first is to identify this deeper or perhaps the deepest level of experience. This deepest level of experience is regressively argued based upon what persists in our perceptions. The corresponding transcendental reasoning follows roughly the same line as taken in First Analogy for deriving and clarifying the meaning or sense of the Principle of Substance. There too, the regressive reasoning was based upon the general observation of relation between what changes and what remains of an object. Here the object is supposed to be the empirical self for the existence of which we claim to be conscious. Here too, we find distinction between what changes and what remains or persists. What persists is not part of this self, since according to Kant, this persistence is what has to be presupposed for the very existence of this self, meaning that persistence or permanence is the transcendental precondition for the possibility of empirical self and it is a general thesis that the transcendental of $X$ cannot be part of $X$. So, this persistent thing must be outside me and is not the result of some representation in me. This establishes that my consciousness of my existence is the result of what actually exist outside its subjective dimension.

But now the question arises: "How does this contribute to the occlusion of phenomenology?" The occlusion is twofold. From one side, this takes the detour through the indirect path from how we find ourselves temporally determined in time where one of the most primary temporal determinations involves the Grundsatz of substance (First Analogy) which is not some originary intuition or visibility of time but only a transcendental determination of time as order relation. Furthermore, this subordination of self-affection under the affection from outer or external world involves the latter's correlative grounding in the ways this self-affection is determined by external world via figurative synthesis, which we have already seen in the preceding subsection to be occlusive of phenomenology.

\section{Conclusion}

The present investigation has explicated Ricoeur's first aporia of time at the level of Kant vs. Husserl with the problematics of visibility vs. non-

(c) 2021 Hafiz Syed Husain

https://www.kritike.org/journal/issue 28/husain june2021.pdf

ISSN 1908-7330

(cc) BY-NC-ND 


\section{RICOEUR'S FIRST APORIA}

visibility as its guiding theme. Visibility of time in phenomenology amounted to an act of reflection that is originarily self-giving. Husserlian phenomenological description of time and its corresponding intentional fulfillment at the level of reflection is argued to be that originarily self-giving act. However, limitations of this description and its method revealed the lack of phenomenological visibility of time. This led to Kantian transcendental ideality of time as its anti-thesis: the invisibility of time. However, Kant's ideality of time also suffered the limitations revealed by accounting how it concealed, i.e., implicitly presumed phenomenology of time with a possibility of a vague-vision: Ricoeur's temporal horizon. But, major contours within transcendental account of the ideality of time also showed that no such recourse to vague-vision is permissible. Thus, visibility leads to invisibility and conversely, invisibility leads to visibility without resolution such that the whole account is also not viciously circular. It is not viciously circular because we are not being led back to the original Husserlian position of visibility from Kant's position of invisibility. Instead of visibility, we are being led to the vague-vision, or Ricoeur's temporal horizon (or partial visibility). However, this vague-vision is neither attested by Husserlian phenomenology, nor by Kant's transcendental philosophy. So, the problematics stands, and thus, we have the aporia of time. But more importantly, the aporia is meaningful or productive. It has guided us towards a new philosophical investigation of time inasmuch as we keep the valid aspects of both Husserl and Kant and, instead of being dogmatically guided by the themes of visibility or invisibility, we let ourselves be guided by the new idea we just discovered: the vague-vision.

Department of Philosophy, University of Karachi, Pakistan Department of Mathematical Sciences, Federal Urdu University of Arts, Science \& Technology, Pakistan

\section{References}

Ameriks, Karl, "Kant's Transcendental Deduction as a Regressive Argument," in Kant-Studien, 69 (1978), 273-287.

Aristotle, Physics, in The Complete Works of Aristotle, ed. by Jonathan Barnes (New Jersey: Princeton University Press, 1991).

Engelland, Chad, Heidegger's Shadow: Kant, Husserl, and the Transcendental Turn (New York: Routledge, 2017).

Guyer, Paul, Kant and the Claims of Knowledge (New York: Cambridge University Press, 1987). , Kant (New York: Routledge, 2006).

(c) 2021 Hafiz Syed Husain https://www.kritike.org/journal/issue 28/husain june2021.pdf

ISSN 1908-7330

(c) ) BY-NC-ND 
Husain, Hafiz Syed, "Schleiermacher's Universal Hermeneutics and the Problematics of Rule-Following," in Science \& Philosophy, 6 (2018), 314.

"Philosophical Reflections on Research Methodology for Social Sciences," in Beytulhikme: An International Journal of Philosophy, 9 (2019), 585-596.

"St. Augustine's Confessions vs. Aristotle's Physics: Two Rival Conceptions of Time in the History of Western Thought," in Iliria International Review, 9 (2019), 231-253.

Husserl, Edmund, Ideas Pertaining to a Pure Phenomenology and to a Phenomenological Philosophy: First Book, trans. by Fred Kersten (Hague: Martinus Nijhof, 1983). On the Phenomenology of the Consciousness of Internal Time, trans. by J. B. Brough (Dordrechts: Kluwer Academic Publishers, 1991). Logical Investigations Vol. 1, trans. by John N. Findlay (New York: Routledge, 2001).

Kant, Immanuel, Critique of Pure Reason, ed. and trans. by Paul Guyer and Allen W. Wood (New York: Cambridge University Press, 1998).

Matherne, Samantha, "Kant and the Art of Schematism," in Kantian Review, 19 (2014), 181-205.

Ricoeur, Paul, Time and Narrative Vol. I, trans. by Kathleen McLaughlin and David Pellauer, (Chicago: The University of Chicago Press, 1984).

Time and Narrative Vol. III, trans. by Kathleen McLaughlin and David Pellauer (Chicago: The University of Chicago Press, 1988).

Smith, A. D., Husserl and the Cartesian Meditations (London, New York: Routledge, 2003).

Zahavi, Dan, "Inner Time-Consciousness and Pre-reflective Self-awareness," in The New Husserl: A Critical Reader, ed. by Donn Welton (Bloomington: Indiana University Press, 2003), 157-180.

(C) 2021 Hafiz Syed Husain https://www.kritike.org/journal/issue 28/husain june2021.pdf ISSN 1908-7330 